\title{
Sustainable development goals and indicators: can they be tools to make national budgets more sustainable?
}

\author{
ELISABETH HEGE, MSc* \\ LAURA BRIMONT, PhD* \\ FÉLICIEN PAGNON, PhD candidate*
}

\author{
Article** \\ JEL: H61, H83, Q01 \\ https://doi.org/10.3326/pse.43.4.5
}

\footnotetext{
* The authors would like to thank the two anonymous referees for helpful comments on the paper.

${ }^{* *}$ Received: August 14, 2019

Accepted: October 7, 2019
}

\author{
Elisabeth HEGE \\ Institut du développement durable et des relations internationales (IDDRI), 41 rue du Four 75006 Paris \\ e-mail: elisabeth.hege@iddri.org \\ ORCiD: 0000-0002-6588-9459 \\ Laura BRIMONT \\ Institut du développement durable et des relations internationales (IDDRI), 41 rue du Four 75006 Paris \\ e-mail: laura.brimont@iddri.org \\ ORCiD: 0000-0001-5211-3443 \\ Félicien PAGNON \\ IRISSO, UMR CNRS 7170, Université Paris-Dauphine, PSL (Paris Sciences et Lettres), \\ Institut du développement durable et des relations internationales (IDDRI), 41 rue du Four 75006 Paris \\ e-mail: felicien.pagnon@sciencespo.fr \\ ORCiD: 0000-0003-3083-9299
}


Abstract

This article explores the use and added value of the Sustainable Development Goals (SDGs) and indicators in the budgeting process. Several countries have announced in their voluntary national reviews (VNRs) their intention to use the SDGs in their budgetary processes, but few have specified why it would be relevant to do so, or how it could be implemented. Based on nine case studies conducted through interviews, we found that SDG budgeting is still in its infancy. We nevertheless identified four ways in which countries are starting to integrate the SDGs into budgeting processes. Most of the countries we studied either map their budgets against the SDGs or include qualitative reporting in their main budget document. Less often, countries use the SDGs to improve their budget performance evaluation system or as a management tool for resource allocation. Most of the countries follow a technical approach. Only rarely are the SDGs used politically or referenced in the budgetary debate.

Keywords: budget, sustainable development, new wealth indicators

\section{INTRODUCTION}

The seventeen Sustainable Development Goals (SDGs) of the UN's 2030 Agenda for Sustainable Development were adopted by all member states in September 2015. They set an ambitious agenda, aiming to end all forms of poverty, to fight against inequalities, to build peace and tackle urgent environmental issues while also ensuring that no one is left behind. The Agenda's 169 targets and the over 200 indicators that were adopted later on transform an abstract sustainable development concept into concrete measures of progress (United Nations, 2015). While businesses and non-governmental organizations (NGOs) are called to take an active role in the implementation of the SDGs, it is national governments that are primarily responsible for realizing this transformation.

Hence, embedding the SDGs into policy planning at the state level is key towards their achievement. Herein, the budgeting process constitutes a strategic entry point for the integration of the SDGs into national policy planning. In a budgeting process all policies come together and it is therefore as transversal in nature as the Agenda. The way a state decides what to tax and levy charges on (revenue raising) and where to allocate those resources (expenditure) directly affects the achievement of the SDGs. Therefore, it is of strategic importance to study the way countries use the SDGs in their budgeting processes.

Of the 64 countries that submitted a national voluntary report (VNR) during the 2016 and 2017 sessions of the High-level Political Forum (HLPF), 24 mentioned ongoing measures to link the SDGs to the national budget, or said that they had considered such action ${ }^{1}$. However, these reports are not particularly clear on how

\footnotetext{
${ }^{1}$ Based on the authors' analysis of voluntary national reports from 2016 and 2017, these countries are: Afghanistan, Belize, Maldives, Finland, Norway, Italy, Denmark, Costa Rica, Indonesia, Kenya, Uganda, Mexico, Colombia, Montenegro, Philippines, Thailand, Egypt, Ethiopia, Honduras, Sierra Leone, Nepal, Nigeria, Madagascar, Argentina.
} 
countries plan to use the SDGs in their budgetary processes and why they aim to do this (Niestroy et al., 2018). The objective of this article is to give insights into the different uses of the SDGs in budgeting processes and into the potential added value of the methods and tools developed by countries (Hege and Brimont, 2018) 2 .

\section{METHODOLOGY}

\subsection{THEORETICAL FRAMEWORK}

While the SDGs are a new agenda, the role and use of indicators to steer public action has been widely explored by the literature in social sciences. First, indicators are used as tools of governance. Since the 1990s, indicators have been widely developed to guide public policies in global governance (Davis et al., 2012), be this to generate standards, to help decision-making, to contest established norms and policies (Davis, Kingsbury and Engle Merry, 2012), or to distribute attention or allocate scarce resources (Rottenburg, et al., 2015). In this article we investigate different ways in which countries use the SDGs, both as political objectives and indicator-based instruments.

On the role of objectives, Young (2017) writes that governing through goals is a strategy that seeks to guide collective action through the definition of priorities; the mobilization of actors capable of responding to these priorities; the formulation of targets and measures of progress. It also seeks to provide a medium- to long-term vision. The challenge is that these priorities then impact the allocation of resources, including national budgets. For goals to have this effect, campaigning activities are needed to communicate the goals and convince the relevant actors to allocate resources for their achievement (Young, 2017).

SDGs could function as public action instruments. Such instruments may consist of legal rules, technical norms and accounting instruments, which tend to be used as a way to freeze administrative practices and to avoid political debate by routinizing practices of public agents (Lascoumes and Le Galès, 2004; 2007; Chiapello and Gilbert, 2013). They encapsulate an "implicit political theorization" in technical devices. Budgetary performance evaluation instruments are a specific form of such devices and deserve attention (Perret, 2008; Ogien, 2013). Since the 1990s, more and more countries have adopted performance-based budgeting. This trend is linked to the emergence in the 1980s of the New Public Management approach, an ideology that claims to steer public action according to performance but that has been criticized for generating competition and new costs (Bezès and Demazière, 2011; Muller, 2011). Performance-based budgeting derives from performance indicators, the use of which has become increasingly significant in state governance (Bezès and Siné, 2011). This means that budget lines are organized according to political objectives, each one monitored with goals and indicators.

Following the above literature review, we have several assumptions about the reasons for incorporating SDGs into the budget process. The first is that this can

${ }^{2}$ The results of this study were first presented in the format of a working paper (Hege and Brimont, 2018). 
improve policy coherence, which is one of the objectives of the SDGs (SDG 17.14) (Vaillé and Brimont, 2016). Coherence can have two meanings in a budgetary context: firstly, a coherent budget avoids conflicts between different resource allocations, i.e. one budget decision does not have a negative effect on another. For example, budget proposals for transport and agriculture must go hand in hand with climate objectives. Second, a coherent budget should be in line with a state's international commitments, among which is the 2030 Agenda. Even though such commitments are rarely binding ${ }^{3}$, they encourage successive governments to keep these medium-term objectives in mind and incorporate them into their political actions and thus their budgets ${ }^{4}$. So, a budget aligned with the SDGs means that it should reflect the goals and targets of the SDGs and avoid conflict among them. This poses the question as to whether administrations are able to identify the budgetary requirements that specific goals or targets deserve. For example, where does professional education fit in the SDG classification? How do you determine budget expenditure for road infrastructure knowing that it could benefit Goal 9 (Infrastructure) and Goal 11 (Sustainable Cities) but also damage Goal 13 (Climate Action) and Goal 15 (Life on land)? We have to be aware that budget structures do not correspond to that of the SDGs and that assessing budget coherence can be challenging.

The second assumption is that SDGs can increase accountability. Historically, indicators and evaluation play an important role in the democratic debate (Porter, 1995, Rosanvallon, 2015). Numbers reflect the general demand for objectivity in public affairs. Quantified evaluation might encourage governments and officials to make their action accountable and transparent. To this end, forging links between budgets and SDGs, especially the indicator framework, can reveal the progress of a country towards the SDGs and help assess the government's performance. While most countries use performance-based budgeting that relies on results indicators, the SDGs could add an additional, holistic layer of criteria to evaluate the sustainability of a budget (Niestroy et al., op. cit.). The SDGs could serve as an evaluation framework to provide a more comprehensive assessment of budget proposals and therefore increase transparency for non-governmental actors, notably parliament and civil society. Indicators are tools, which can be appropriated either by institutions to justify public policies or by challengers to criticize them (Bruno, Didier and Prévieux, 2014). However, the publication of indicators does not necessarily mean they will have an impact on the public debate, especially if the indicator is fairly technical and/or becomes lost among several hundred other indicators for assessing budget performance and if no one is campaigning around them.

\footnotetext{
${ }^{3}$ The recent decision of the Trump government to withdraw from the Paris agreement highlights the fragility of international commitments.

4 "Closely aligning budgets with the medium-term strategic priorities of government" is the second out of ten principles of good budgetary governance, established by the OECD Council on budgetary governance (OECD, 2015).
} 
A third assumption is that SDGs could help make national budgets more comparable and standardized and thus contribute to the global ranking of sustainable development policies. One consequence of indicator multiplication is the comparison and ranking of country performances, which has a wide variety of impacts on governance (Bruno and Didier, 2013; Desrosières, 2014), both positive and negative. We could for instance imagine that each state could include an analysis of their budget according to the SDGs in the progress reports that are annually submitted to the HLPF. This could play a positive role in the transition towards sustainable development if it promotes exchanges between policymakers and experts from different countries and feeds the international debate with collective intelligence. It could also serve as a tool for civil society to hold states accountable for their commitments.

This study will analyze the different ways in which countries use the SDGs in the budgeting process and whether they do so for any of the purposes mentioned above.

\subsection{METHODS}

This article is largely based on 19 semi-structured interviews, conducted between February and June 2018, with administration representatives from case-study countries $^{5}$ and experts. Countries were identified for case studies on the basis of the voluntary national reviews submitted at the 2016 and 2017 HLPF sessions and on an interview with the representative of the French administration on the European Sustainable Development Network (ESDN) ${ }^{6}$. Three other organizations which have published on the topic, were also interviewed: the International Budget Partnership (IBP), an international NGO working with civil society to make public finance systems more transparent and accountable; the Organization for Economic Cooperation and Development (OECD); and the United Nations Development Program (UNDP) Asia and the Pacific. Interviews with representatives from these organizations helped us to identify further potential case-study countries.

During this pre-sampling phase, we identified about 30 countries of interest for our article. As we did not have the relevant contacts for each one, we contacted 18 of these countries (one in fact being a subnational entity). Then, representatives from nine countries accepted an interview. The sample covers a wide geographic range and represents various stages of progress towards the SDGs: Colombia, Mexico, France, Finland, Norway, Sweden, Slovenia, Afghanistan and the Northeast Indian State of Assam. The latter illustrates that similar initiatives are undertaken at the subnational level. The interviews mostly focused on the state of SDG implementation in each country (political support, institutional arrangements, definition of a strategy, etc.) and the objectives and ways in which the SDGs are

\footnotetext{
${ }^{5}$ In addition to our case-study countries for which we conducted in-depth analyses, we also obtained relevant information from other countries.

${ }^{6}$ This is an informal network of public administrators and other experts dealing with sustainable development strategies in Europe. The representative of the French administration is Stéphane Bernaudon from the Ministry of Ecological and Solidary Transition.
} 
used in the budgeting processes. In part 2.1 we have presented our initial assumptions regarding the added value of integrating the SDGs into budgeting processes, which we put to the test during our interviews. Given the size of the sample these results need to be read with caution.

\section{RESULTS}

\subsection{IMPROVING THE BUDGET PROPOSAL NARRATIVE}

The first method by which governments integrate SDGs in their budgets that we identified is that they include qualitative - and more rarely quantitative - elements on SDG implementation in the budget documents they propose to parliament. These reports can take different forms. In Finland, during the preparation of the 2018 budget, the Ministry of Finance asked each ministry to include a short paragraph under each of the main titles in the budget proposal (Niestroy et al., 2019). In these paragraphs, ministries provided information on how sustainable development would be reflected in their sectoral policies during the 2018 financial year. In Norway, each ministry is responsible for one SDG or several. As in Finland, each ministry writes a paragraph about their activities in relation to the goal(s) they are responsible for, both from the domestic and international points of view to demonstrate the link between their budget proposal and its contribution to achieving the SDGs. These draft paragraphs are sent to other ministries for review, before the Ministry of Finance compiles the texts and includes them in a chapter on SDG implementation, which is added to the main document of the budget proposal (De Temmerman, 2019). In Sweden, ministries are encouraged to show the link between their area and the SDGs in budget documents in a descriptive way. The SDGs are handled differently by different ministries, while some reference them more often than others. There was little connection made in the social sectors. To use the SDGs in these sectors, a discussion process is required to define what the SDGs on poverty eradication and universal health care, for example, could mean for Sweden, and how they could be used to discuss the main challenges in a country like Sweden.

Several lessons can be learned from these experiences. Firstly, the political will to incorporate sustainable development elements into budget proposal documents had in some countries existed before the arrival of the SDGs. In Norway, a chapter on climate change has been included in the report to parliament for eleven years, while the country developed its own sustainable development indicators in $2005^{7}$. Secondly, budget documents have an official size limit and do not allow space for a comprehensive report on all SDGs and targets. Thus, the SDGs need to be organized and a focus needs to be found that reflects the national context. Finland has carried out an independent gap analysis and chosen two overarching themes for national SDG implementation (carbon neutral and resource-wise Finland); these

\footnotetext{
${ }^{7}$ Remember that Norway has a long history with sustainable development since it is a former Norwegian Prime Minister, Gro Harlem Brundtland who chaired the World Commission of Environment and Development in charge with the report Our Common Future (1987), the framing of which is considered the birth of the concept of sustainable development.
} 
two themes can then be reflected in the budget document. The Finns plan to include a concrete analysis on the link between budgetary appropriation and SDGs in the General Strategy Outlook section of the budget that will concentrate on one of the focus areas in the Government's implementation plan. Hence, integrating the SDGs in the budget document requires the previous identification of the most challenging goals or targets. The SDG framework is inherently broad in that it concerns all countries in the world, and reporting on the targets that have already been reached would make no sense. The Norwegian Forum for Environment and Development, a network of 50 NGOs from different sectors ${ }^{8}$, which monitors SDG implementation, explained that its accountability work could be more targeted if the government had an action plan for SDG implementation that identifies clear national objectives and indicators based on the specific challenges faced by that particular country. The need for a national translation of the SDGs and their targets and indicators into a strategy or action plan, was underlined several times during the interviews. Such a need corresponds to the necessity of a national appropriation of transnational agendas, to produce coherent public policies at the state scale (Hassenteufel, 1995). Whether this kind of report serves the political debate, depends on its use by non-governmental actors, notably parliament and civil society. Although it is too early to say for sure, Finland appears to be well on its way to strengthen accountability within the budget process due to the SDGs. This has occurred because from the very beginning civil society has been allowed to participate in the deliberation process on how to link the SDGs to the national budget, through the organization of a multi-stakeholder workshop. To enhance the process, the Ministry of Finance organized a multi-stakeholder workshop in November 2017. The aim of the workshop was to discuss and gather ideas on how sustainable development could be identified and made more visible in the budget, and how the link could be developed between the budgetary process and the sustainable development agenda (Niestroy et al., 2019). The findings of the workshop are being used in the preparation of the 2019 budget and beyond.

In Norway where the SDGs have been integrated into the main budget document since 2016, the accountability feedback loop functions quite well. The Norwegian NGO Forum for Environment and Development often refers to the SDG chapter in the budget report (Forum, 2017). In their 2017 report on SDG implementation in Norway, they discuss the relevance of the information provided by the government, highlight neglected issues and provide recommendations. This means that SDGs can indeed be used as tools of advocacy and contestation (Bruno, Didier and Prévieux, 2014; Davis, Kingsbury and Engle Merry, 2012). For example, the NGO stated with regret that "In the 2017 National Budget, Goal 3 is hardly mentioned, stating only that public health in Norway is good, that healthcare is good, and that health is a priority in Norwegian development assistance" and that "The government has also avoided mentioning that Norway's budget for renewable

\footnotetext{
${ }^{8}$ Mainly development, environment, peace, human rights and humanitarian aid, covering many of the goals
} of the SDGs. 
energy development assistance was almost halved between 2014-2015 and 20162017" and that "the measures presented as examples do not show any plans to stimulate a generally lower consumption pattern among Norwegian consumers, despite the fact that it is clear that most Norwegians use far more resources per capita than the capacity of the planet can tolerate." In conclusion, the government's report on the SDGs in the budget process facilitates the accountability role of the NGOs, which is key to pushing forward SDG implementation at the national level (Hege and Demailly, 2018). We must add that Norwegian civil society is accustomed to commenting on the budget proposal and that there is a culture of debate around budget proposals with civil society organizations (CSOs) being invited to participate in parliament during the debate. This practice can, of course, facilitate the accountability role of independent actors in the budget process, including the control of the government's commitment to SDG implementation.

Finally, our observations led us to conclude that countries tend to limit reporting to SDGs directly related to the activities of the respective ministries. While this might increase accountability, it does not automatically improve policy coherence.

\subsection{MAPPING AND TRACKING THE BUDGETARY CONTRIBUTION TO THE SDGs}

The second way to account for the SDGs in the budget process is to monitor the budget according to the SDGs. The Mexican government links its budgetary programs ${ }^{9}$ to SDG goals so they can determine the percentage of a goal linked to any budgetary program and conversely the number of budgetary programs linked to each goal (Ministry of Finances and Public Credit and UNDP, 2017). The Colombian government is currently doing similar work, having developed an automatic text analysis tool to identify links between budgetary programs and each SDG goal ${ }^{10}$.

Nepal and the Indian State of Assam have gone a step further, coding their budget according to the SDGs to keep track of the allocation of resources to each SDG goal (UNDP, 2010a; 2017b)). These two entities have tracked SDG relevant resources at the budget line level. Figure 1 shows the results of this mapping.

Mapping the contribution of budget programs to the SDGs or the tracking of SDG-relevant budget lines is not easy as they often apply to several SDGs. Generally, the assumptions underlying the mapping and tracking system used were made by each ministry or department, which means that there can be variation between countries. Often, these exercises were only partially accomplished. In Nepal, SDG coding was only done for development programs and did not take into account defense or general administration that was not directly related to any of the SDGs. In this way, SDG coding was applied to roughly two thirds of the

\footnotetext{
${ }^{9}$ Expenditure category with a common objective.

${ }^{10}$ At the time of the writing of our article, they were still at the pilot project stage.
} 
total budget. Moreover, SDG coding only concerns the state budget, which, is only one component of public spending. Moreover, it does not include the budget for local authorities. However, Colombia plans to make its text analysis tool available to the local authorities so that they can implement the same organizing principle as the central State.

\section{Figure 1}

Budget mapping for Assam and Nepal (expenditure) and Mexico (number of budgetary programs)

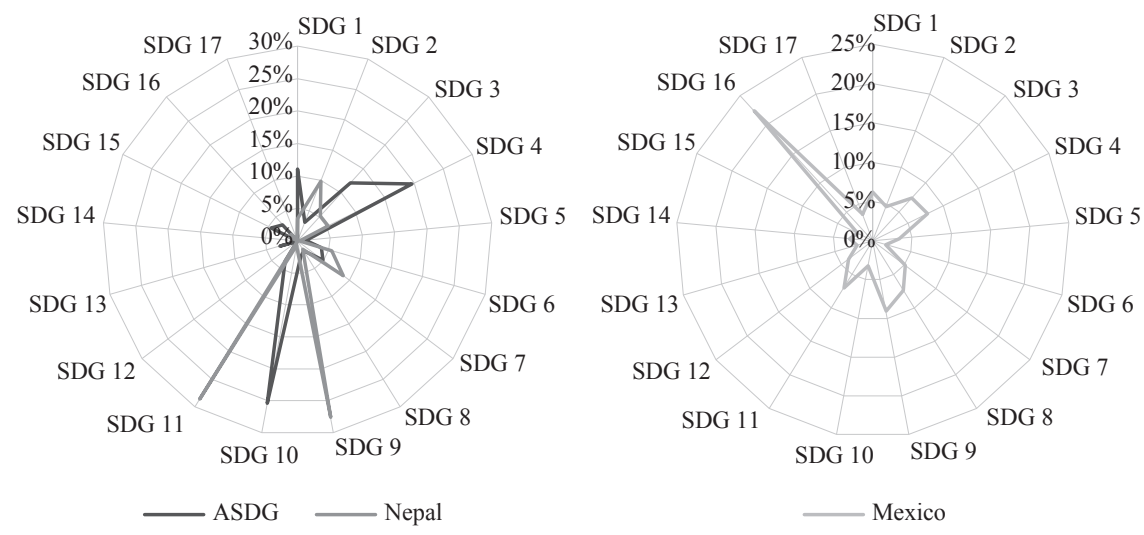

Source: IDDRI, with data from UNDP (2017a, 20a7b) and the Ministry of Finance and Public Credit and UNDP (2017)

The evidence gathered via mapping and tracking exercises could be used for management purposes to orient budget choices and identify priority areas for funding in the context of budget constraints. This seems to be at least partly the case in Assam.

Categorizing spending around the SDGs does not enable us to know how the spending actually impacts SDG achievement. While it improves spending transparency, accountability could be increased by the addition of performance indicators, as is the case in Mexico (see 5.4). This would enable clear connections between spending and outcomes to be established.

It is interesting to note that in our relatively small sample, there is a wide difference in the use of the SDGs in the budget process depending on the country type. High-income countries use the SDGs more as a framework for making qualitative reports on the budget proposal (see 3.1), while low and middle-income countries mainly map the budget according to SDGs to enable the tracking of expenditure on the different goals and/or targets. This could be linked to the desire to meet the expectations of international donors. Hence, a pilot project developed in Colombia aims to signal investment needs to international private and public donors. Thus, SDG coding could be seen as an extension of the existing practices of international aid, like gender budgeting, pro-poor budgeting or "climate-friendly" budgeting (Davis et al., 2012). Another reason for this difference is that these 
countries were already involved with the Millennium Development Goals (MDGs), the UN's development framework that ran from 2000 to 2015, which were replaced by the SGs. There has been criticism that at the time of the MDGs there was no adequate monitoring of the flow of public financial resources invested into the implementation of the goals (Schouten, 2015). The lack of national ownership and transparency sometimes made it difficult to hold governments to account for their contribution to the global agenda. Nevertheless, a number of initiatives did exist to monitor MDG-related spending such as the Government Spending Watch, a joint initiative by Development Finance International and Oxfam (Budlender, 2017).

\subsection{USING THE SDGs AS A MANAGEMENT TOOL FOR NEGOTIATIONS}

Budgets are about prioritization, negotiation and arbitration among different ministries and line agencies. However, there is generally very limited leeway for these decisions due to budget inertia. Some countries mentioned that ministries use the SDGs and the targets to justify their budget proposals and negotiate for more money. In Norway for example, this does happen but it remains an exception and the SDGs are used as one of many arguments. In Assam, the SDGs are now a tool for line departments to obtain priority funding (UNDP, 2017a). In Finland, although the picture is not yet totally clear, the administration hopes that the SDGs will be a beneficial tool that might be able to better direct resource allocation decisions towards sustainable development. As the SDGs are very much in line with general political objectives in Finland, there is a chance that this notion could become reality.

In Afghanistan, the SDGs will be used as a framework to select which grant applications from the provinces will obtain central government funding. So, they will become the main selection criteria for grant applications proposed by the provinces. The idea is that each grant application describes how it will contribute to the SDGs, enabling the Ministry of Economy to prioritize the development projects that are the most interesting. It is also planned to use this framework the better to follow up on projects that are implemented on the territory by public or private actors. This example must be understood in the context of a very limited State budget and a high dependency on international donors.

So there are signs that SDGs are being used as a management and negotiation tool during the drafting of the budget. However, given the relatively little space for new options from one budget to another, the actual consequences in monetary terms remain limited. Moreover, they are rarely the only tool and using the SDGs in this context requires high-level political support for the goals. Without the SDGs reflecting political priorities, it seems difficult to use them as a negotiation tool. In this regard the French case is interesting because it is currently at the beginning of this process and of the design of its roadmap.

Finally, countries that plan to use the SDGs as a negotiation tool in the budgetary process should keep in mind two facts. First, many targets cannot be achieved 
simply by the addition of more money. They also need policies, public norms and regulations. Second, one could imagine that SDGs could be used not only to address the question: "how much should we spend and where?"; but also "how can we spend it better?".

\subsection{IMPROVING BUDGET PERFORMANCE EVALUATION}

The SDGs and their targets and indicators can be used to improve a budget performance evaluation system. Mexico, for example, is revising its budget performance indicators in light of the SDGs. Here it was actually the department responsible for performance budgeting that initiated the integration of the SDGs into the budget system. Mexico has had a budget performance monitoring system for around twenty years and continuously tries to link it to international commitments. The office in charge of budget performance monitoring initiated the integration of the SDGs into the budgetary performance evaluation system. They looked at the SDG indicators and asked ministries what factors they were already measuring. Most issues were covered, but this exercise enabled the identification of indicators that have to be adapted, especially when it comes to environmental issues.

According to the department in charge of this exercise, the advantage of replacing national performance indicators with international ones is to allow international comparability - provided that other countries do the same - which thus increases accountability. Secondly, the 2030 Agenda provides a long-term framework, and its indicators give some stability and credibility to the evaluation system compared to national indicators that can be changed according to politicians.

In an interministerial document (CICID, 2018), France announced in February 2018 that it would align its budget performance indicators with the SDGs "where relevant and possible". France is currently in a process of designing a roadmap for SDG implementation that should be ready by 2019. Integrating the SDGs into the national budget will be one of the topics discussed in the series of multi-stakeholder workshops that will feed into the roadmap.

Slovenia had clearly linked the SDGs to national objectives and adapted them to their national context and challenges prior to adopting 30 Key Performance Indicators (KPIs) to evaluate national development including budget performance. These KPIs indirectly reflect the SDGs but have been nationally translated. This national translation is important to make the SDGs suitable for budget performance evaluation (Niestroy et al., 2019). Therefore, SDG targets need to be translated into clear national objectives. Many SDG targets are formulated as trends with only relative targets. Therefore, Slovenia has carried out a gap analysis and adopted the Slovenian Development Strategy 2030, which has 12 goals and a national development policy program. The country has also developed 30 resultoriented KPIs to influence future budgets, underlining their stance that it makes no sense to have SDG-aligned KPIs for a budget that was not originally planned with the SDGs in mind. Hence the need to translate the SDGs into long-term national 
political targets. Slovenia also plans to integrate strategic development plans from 2020 onwards.

So as the Slovenian example demonstrates, using the SDGs for budget performance evaluation requires some effort to adapt the targets and indicators. In addition, it makes more sense to integrate the SDG indicators in a performance budget evaluation system if they have also been integrated into national political targets. What can maybe be done at a lower cost, is to disaggregate existing budget performance indicators. This could deliver important information that could be used to take into account the "leave no one behind" principle in policy design. Using the SDGs for performance evaluation increases accountability. When it comes to coherence, this depends on the design of the evaluation system and whether or not the indicators reflect interlinkages.

\section{DISCUSSION}

\subsection{WHAT IS THE PURPOSE OF SDGs BUDGETING?}

It is very difficult to say whether the approaches and tools developed by different countries are actually useful for making real progress on reducing inequalities, for concrete policy objectives such as protecting biodiversity and achieving the national challenges required by the SDGs by 2030 . What does emerge, at least to some extent, is whether the tools developed actually contribute to the broader objectives discussed in section 2.1, where in our assumptions we list potential benefits of integrating the SDGs into budgetary processes. Do they, as expected, improve coherence, accountability, and international comparability?

The involvement and leading roles given to finance ministries was often cited by the countries concerned as an advance in terms of coherence. It strengthens coherence in the sense that it forms a link between the SDGs as medium-term strategic goals and the budget. But does it also strengthen coherence in the sense that it reduces conflicting expenditure? To date we have not been able to observe this in the countries interviewed, but this may be due to the use of these tools being still in its infancy. However, we did not get the impression that the tools were specifically developed for this purpose. An exception might be Finland, which, in addition to a summary of budgetary appropriation relevant to the focus areas in the government's implementation plan aligned for the SDGs, has also committed itself to analyze harmful subsidies. As far as accountability is concerned, the qualitative indicator that we used in our questionnaires is to what extent parliamentarians, NGOs or supreme audit institutions use the approach to hold the government to account for their commitment to achievement of the SDGs. In most of the countries, SDG integration into the budgetary process is not yet very advanced. It is therefore too early to say whether the tools are being taken up by different actors to hold the government to account.

In Norway where the SDGs have been integrated into the main budget document since 2016, the accountability feedback loop functions quite well. In some 
countries, SDGs have been used as a tool to improve budget transparency. Whether this information increases accountability is not a trivial matter. It depends on what additional information is made transparent. Presenting budget allocations does not show how much money is actually spent and invested in different targets. Nor does it say whether the way the money is spent actually produces an outcome. This calls for performance indicators and evaluation.

Making SDGs visible, either through mapping or qualitative reporting, does not necessarily mean there would be more effort and/or money for the SDGs. Research on the new indicators of wealth shows that indicators can be used as tools for steering public action if they are used at all stages of public policymaking, both upstream to legitimize and institutionalize a phenomenon and to monitor its evolution and downstream to evaluate the results of a policy strategy (Demailly et al., 2015). In other words, they have to be used in the political debate, both by the government itself but also by external actors like parliament and civil society. Surprisingly, in some of the countries the SDGs are actually used as a negotiation tool. Given the transversal and broad nature of the SDGs this seems counterintuitive at first glance. In Afghanistan for example, the SDGs have been translated into a tool to guide and prioritize funding of different development projects. In other cases, ministries use them as an argument to obtain priority funding, although the argument is only one amongst several and is not the strongest one. In general, to be used as a management tool for guiding allocation choices, a significant effort needs to be made to translate the SDGs to the national context and development challenges. A budget is about priorities and making choices. Accordingly, the SDG framework is too broad to be used directly for this purpose. The SDGs can, however, be used as an opportunity to discuss and identify the medium-term sustainable development challenges in a country. Once this has been done, these priorities should guide budget choices and could be formulated as objectives, measured by indicators, including budget performance indicators (as is the case in Slovenia).

As far as international comparability is concerned, none of the countries studied have gone as far as to revise their budget classification system. Mostly for good reasons, because revising budget classification systems is costly and although the SDGs are there to stay until 2030, it is not clear what will happen afterwards, as some interviewees pointed out. Nevertheless, the international character of the SDGs is actually of value, which is why Colombia revises its performance indicators to align them with the SDGs. This, they hope, will increase transparency with respect to the international community, including donors. Although international comparability can increase accountability vis-à-vis peers and donors, there are limits to their use in international budget comparability. The SDGs need some translation to the national context before they become sufficiently operational to be integrated into a state budget. This works well, so long as these choices do not contradict SDG principles, because it strengthens national ownership. However, there is a trade-off between national translation of the SDGs and international comparability. 


\subsection{IN WHAT OTHER WAYS IS IT POSSIBLE TO USE THE SDGs \\ IN THE NATIONAL BUDGETARY PROCESSES?}

During our desk research and interviews, we came across additional ideas about how countries could integrate the SDGs into their budgetary processes. Although we have not so far observed any instances of countries taking up these ideas, it is nevertheless worth sharing them and briefly discussing their value.

An International Monetary Fund blogpost suggests that an international organization should design a universal SDG budget classification system (Poghosyan, 2016). The advantages would be increased international comparability and a clearer overview than would otherwise result from the sporadic introduction of budget tagging systems applied to cross-cutting SDGs such as gender ${ }^{11}$ or climate change ${ }^{12}$. The risk is ending up with budget databases that are overcrowded with information that will not necessarily be used and might even diffuse the focus on the most pressing issues.

Another risk of a universal SDG budget classification system is decreased national ownership and the domination of the policy agenda by donors (Poghosyan, 2016). Given the high level of civil society participation in the making of the SDGs, one of our interviewees described the SDGs as the "perspective of citizens on their societal problems". The SDGs are formulated as problems to resolve by 2030; organizing and reporting on the budget around these goals might be more attractive for citizens than organizing it around thematic areas like education, and so on. One could think of the SDGs as a basis for developing a budget-reporting dashboard for citizens. Although the information necessary to create such a dashboard is available in some countries, we have not observed any instances of this information being used for any such highly visual dashboard for citizens.

Other approaches aim more at launching a political debate and less at a technical approach. France has started experimenting with the use of 10 "wealth indicators" that are complementary to GDP (such as carbon footprint or healthy life expectancy). In 2015 a law, promoted by Member of Parliament Eva Sas, was adopted, that requires the government to publish an annual report upstream of budget discussions, providing details on France's progress (Loi n²015-411 visant à la prise en compte des nouveaux indicateurs de richesse dans la définition des politiques publiques, 2015). This report then was initially expected to feed into the budgetary debate. However, these indicators have not become firmly established in the French political debate so far. The report having been published with significant delay, it is not yet used by political actors (Pagnon, 2019). There are proposals in France that see the SDGs as an opportunity to give a new lease of life to the 2015 "Sas Act".

\footnotetext{
${ }^{11}$ Gender-responsive budgeting already exists in more than thirty countries.

${ }^{12}$ Examples of countries that have integrated a climate focus into their budgets include Bangladesh, Indonesia, Nepal and the Philippines.
} 
Italy is a similar case. Already in 2011, it launched a set of indicators for equitable and sustainable well-being (BES) to measure progress beyond GDP. In 2016, a law was adopted related to the integration of BES indicators into economic and financial reporting. Following up on this law, four BES indicators were included in the budget ('Economic and Finance document' - annual document that reports the quality and trends of public expenditures) in 2017. In 2018, this number went up to twelve. With the arrival of the SDGs, synergies have been created with this existing initiative (Niestroy et al, 2019). When the National Institute of Statistics published 100 SDGs indicators, in 2017, 38 among them were part of the set of BES indicators.

A network of German NGOs has organized a series of debates on the relevance of SDGs for the German budget. In one study, an NGO called the Global Policy Forum recommends linking the SDGs to spending reviews that are there to assess the actual impact and efficiency of programs and measures in specific policy areas. Assessing the impact of a budget on all SDGs at once would not be manageable, but the NGO recommends that the SDGs should be linked to spending reviews in a continuous cycle (Martens, 2017).

Another step forward would be to link them to public policy evaluation. Courts of audit could play a key role in such evaluations. In fact, Supreme Audit Institutions (SAIs) are increasingly active as accountability actors in national SDG implementation processes (Guillan-Montero, Le Blanc, 2019). The IDI, Development Initiative of the International Organization of SAIs has launched a capacity building program on 'Auditing Sustainable Development Goals' and has been a driving force in this dynamic. In their SDG audits, not all but some SAIs make reference to national budgets and financing frameworks. As an example, the National Audit Chamber of the Republic of Sudan regrets that "there are no arrangements at the level of the federal finance ministry to fund implementation of the Sustainable Development Goals" (NAC, 2018); the German Bundesrechnungshof recommends the quality of sustainability assessments of subsidies be improved and the government's SDG communication strategy (Bundesrechnungshof, 2019) be properly financed; Burkina Faso's Court des Comptes recommends that performance-based budgeting be promoted at the local level as well and that an integrated financing framework for the SDGs be set up (Cour des Comptes, 2019).

Finally, although the focus of this report is on governments, it is worth mentioning that several tools are available for CSOs to use the SDGs in their budget advocacy. Examples include the analysis of the state budget from an ecological, social and human rights perspective, or designing an alternative state budget that better reflects the commitment to these goals, and that can be used as an advocacy and awareness-raising tool (Martens, 2017). 


\subsection{CONDITIONS FOR A SUCCESSFUL INTEGRATION OF THE SDGs INTO BUDGETARY PROCESSES}

There are different ways to integrate the SDGs into national budgetary processes. Some are quite complicated and time-consuming. The ultimate goal of all of these different tools should be to make progress tackling the challenges and the worrying long-term trends that are highlighted by the Agenda 2030 and its SDGs. Whether these tools help to make SDG implementation a higher priority in countries and encourage the appropriate budgetary decisions depends on a number of factors that are linked to a country's broader SDG implementation strategy and the mobilization of actors around these global goals. Based on our interviews we identified a number of factors that make tools more likely to have a real impact on the budgetary orientations of a country for the good of the SDGs. Three characteristics seem especially important to ensure that SDG integration into budgetary processes is a useful exercise.

Table 1 gives a summary of the potential conditions for success according to the country interviewed. Countries intending to integrate the SDGs into their national budgets may find it useful to consider these conditions before starting the process ${ }^{13}$.

The first relates to the broader SDG implementation strategy of a country. To what extent does a government translate the broad SDG framework to suit its national context and sustainable development challenge? As mentioned above, the SDGs require some translation to adapt to the national context before becoming sufficiently operational for their integration into a state budget. It is easier to link the SDGs to the budget if there is a national implementation plan or strategy that formulates national priorities. These priorities can be cross-sectoral ${ }^{14}$. This process can be supported by an independent gap analysis but, ultimately, it also involves political decisions. Thus, high-level political support is an important condition for success. The second is the degree of involvement of finance ministries. Is such a ministry piloting or supporting the exercise? Did it even initiate the exercise? Or does it reluctantly only follow or even block its progress? The latter was reported in some interviews, and it was found to severely compromise the success of SDG integration into the budgetary process in terms of increasing coherence and accountability. Another issue is whether a ministry of finance uses the SDGs as a management tool to negotiate on allocations and to avoid conflicts within the overall state budget. One signal that the SDGs have an impact, at least marginally, as an argument in budget negotiations, is that ministries actually voice their concerns on some SDGs and use them to defend their proposals and fight for their budget share.

Thirdly and finally, to impact the political debate and increase accountability, it is essential that the tools developed are taken up by actors such as NGOs, parliamen-

\footnotetext{
${ }^{13}$ We have not included France and Sweden in the table because although these countries are considering integrating the SDGs into their budgetary processes, this process is not yet very advanced.

${ }^{14}$ Some countries avoid using the term "priorities" because of the indivisible nature of the SDGs. Instead they use terms such as "accelerators" or "cross-cutting themes".
} 
tarians and supreme audit institutions, as these actors are crucial in holding gov-

ernments to account regarding their commitments to the Agenda 2030.

\section{TABLE 1}

Checklist of the necessary conditions according to the case studies for successful SDGs integration into the budgetary process

\begin{tabular}{|c|c|c|c|c|c|c|c|}
\hline & $\begin{array}{c}\text { Assam } \\
\text { (Indian } \\
\text { province) } \\
\end{array}$ & $\begin{array}{l}\text { Afghani- } \\
\text { stan }\end{array}$ & $\begin{array}{l}\text { Colom- } \\
\text { bia }\end{array}$ & $\begin{array}{l}\text { Fin- } \\
\text { land }\end{array}$ & $\begin{array}{l}\text { Mex- } \\
\text { ico }\end{array}$ & $\begin{array}{l}\text { Nor- } \\
\text { way }\end{array}$ & $\begin{array}{c}\text { Slo- } \\
\text { venia }\end{array}$ \\
\hline $\begin{array}{l}\text { Year in which SDGs } \\
\text { were (or are planned } \\
\text { to be) integrated into } \\
\text { the budgetary process }\end{array}$ & 2016 & 2019 & 2018 & 2018 & 2018 & 2016 & 2020 \\
\hline \multicolumn{8}{|c|}{ Extent to which the SDGs have been translated into the national context } \\
\hline $\begin{array}{l}\text { National } \\
\text { implementation plan } \\
\text { or strategy }\end{array}$ & $\mathrm{X}$ & $\mathrm{X}$ & $\mathrm{X}$ & $\mathrm{X}$ & $\mathrm{X}$ & & $\mathrm{X}$ \\
\hline $\begin{array}{l}\text { Nationally translated } \\
\text { targets or priorities }\end{array}$ & & $\mathrm{X}$ & $\mathrm{X}$ & $\mathrm{X}$ & $\mathrm{X}$ & & $\mathrm{X}$ \\
\hline $\begin{array}{l}\text { Gap analysis to identify } \\
\text { national challenges }\end{array}$ & & & $\mathrm{X}$ & $\mathrm{X}$ & & & $\mathrm{X}$ \\
\hline $\begin{array}{l}\text { High level political } \\
\text { support for the SDGs }\end{array}$ & $\mathrm{X}$ & $\mathrm{X}$ & $\mathrm{X}$ & $\mathrm{X}$ & $\mathrm{X}$ & $X$ & \\
\hline
\end{tabular}

$\begin{aligned} & \text { Exercise initiated by } \\ & \text { Ministry of Finance }\end{aligned}$
$\begin{aligned} & \text { Ministry of Finance } \\ & \text { piloting the approach }\end{aligned}$

"Some countries avoid using the term "priorities" because of the indivisible nature of the SDGs, highlighting the importance to work towards the Agenda 2030 as a whole. Instead they focus on a selection of "accelerators" or "cross-cutting themes".

Source: table created by the authors based on semi-structured interviews. 
To date, 24 countries have announced that they will link the SDGs to their national budgetary processes. Most countries are still at an early stage of working out a relevant way to make this link, while others are starting to experiment with the tools and methods they have developed.

We have identified four ways in which countries use the SDGs in their budgetary processes. Most countries we studied either map their budgets against the SDGs or conduct a qualitative report on the budgetary contribution to the SDGs, which they include in their main budget document. Less often, countries use the SDGs to improve their budget performance evaluation system or as a management tool for resource allocation and negotiation. The different tools identified are not mutually exclusive and could actually support each other. We have also highlighted other potential ways in which the SDGs can be used in budgetary processes.

As yet, the tools developed for SDG integration into budgetary processes mostly serve to make the government's commitment to the SDGs more transparent. This improved transparency gives a picture of the current budgetary priorities in relation to the SDGs, but it does not automatically lead to more coherent management or to a discussion about the reorientation of resources to better target the most challenging sustainability issues. Neither does it automatically lead to actors using this improved transparency to hold governments to account for their commitments (De Temmerman, 2019). This requires parliamentarians, civil society and ministries to actually use the SDGs, for example to improve the budget debate. In some countries, supreme audit institutions or non-state actors like NGOs actually use this information to hold governments to account.

Integrating the SDGs requires a process of translation that links the SDG framework with national objectives. This is most easily accomplished where there is high-level political support for the SDGs. The use of SDGs as a tool in the budgeting process can actually be seen as a sign of political commitment, as high-level political support was relatively strong in the majority of countries we studied.

The objective of this article was to give insights into the different uses of the SDGs in budgeting processes and into the potential added value. This should be put into perspective. First, the implementation of sustainable development is not just a matter of financial means, and SDG spending reflects only part of the political effort towards the achievement of the SDGs. To be successfully attained, some SDGs need regulatory and legal measures as much as they do financial support; examples are Goal 10 (reduced inequalities) and Goal 12 (responsible consumption and production). Secondly, making SDGs visible in the budgeting process does not necessarily mean that more effort and/or money will be made available for sustainable development. Research on the new wealth indicators shows that indicators can be used as tools for steering public action if they are used at all stages of public policy making, both upstream to legitimize and institutionalize a 
phenomenon and to monitor its evolution, and also downstream to evaluate the results of a policy strategy (Demailly et al., 2015). In other words, to be a useful tool, SDGs have to be used in the broad political debate, and not only at the budgetary debate stage.

\section{Disclosure statement}

No potential conflict of interest was reported by the authors. 


\section{REFERENCES}

1. Bezès, P. and Demazière, D. (eds.), 2011. Introduction du dossier débat: New Public Management et professions dans l'État: au-delà des oppositions, quelles recompositions? Sociologie du Travail, 53(3), pp. 293-348. https://doi. org/10.1016/j.soctra.2011.06.003

2. Bezès, P. and Siné, A., 2011. Gouverner (par) les Finances Publiques. Paris: Presses de Sciences Po.

3. Bruno I. and Didier, E., 2013. Benchmarking. Paris: La Découverte.

4. Bruno, I., Didier, E. and Prévieux, J., 2014. Statactivisme. Paris: La Découverte.

5. Budlender, D., 2017. Tracking Spending on the SDGs: What Have We Learned from the MDGs? Washington, D.C.: International Budget Partnership.

6. Bundesrechnunghof, 2019. Der nationalen Umsetzung der Ziele für Nachhaltige Entwicklung der Vereinten Nationen - Agenda 2030. Berlin: Bundesrechnunghof.

7. Chiapello, E. and Gilbert, P., 2013. Sociologie des instruments de gestion. Paris: La Découverte.

8. Cour des Comptes, 2019. Rapport définitif de l'audit de performance de l'état de préparation pour la mise en oeuvre des Objectifs du Développement Durable (ODD) au Burkina Faso. Paris: Cour des Compte. https://doi.org/10.1787/ 888933538584

9. Davis, K. [et al.], eds., 2012. Governance by indicators. Oxford: Oxford University Press.

10. Davis, K., Kingsbury, B. and Engle Merry, S., 2012. Indicators as a technology of global governance. Law and Society Review, 46(1), pp. 71-104. https:// doi.org/10.1111/j.1540-5893.2012.00473.x

11. De Temmerman, J., 2019. Implementation of the Sustainable Development Goals: synergy needed on the part of all stakeholders, from parliaments to local authorities. Strasbourg: Council of Europe, Committee on Social Affaires, Health and Sustainable Development.

12. Demailly, D. [et al.], 2015. New indicators of wealth on European governance. IDDRI Working Paper, No. 17/15. Paris: IDDRI.

13. Desrosières, A., 2014. Prouver et gouverner: une analyse politique des statistiques publiques. Paris: La Découverte. https://doi.org/10.3917/pro.342.0090

14. Finnish National Commission on Sustainable Development, 2016. The Finland we want by 2050. Society's Commitment to Sustainable Development. Helsinki: Finnish National Commission on Sustainable Development.

15. Forum, 2017. How the UN Sustainable Development Goals can be reached in and with Norway by 2030. Oslo: Norwegian Forum for Development and Environment.

16. Guillan-Montero, A. and Le Blanc, D., 2019. The role of external audits in enhancing transparency and accountability for the Sustainable Development Goals. DESA Working Paper, No. 157. https://doi.org/10.18356/3fe94447-en 
17. Hassenteufel, P., 2005. De la comparaison internationale à la comparaison transnationale. Revue française de science politique, 55(1), pp. 113-132. https://doi.org/10.3917/rfsp.551.0113

18. Hege, E. and Brimont, L., 2018. Integrating SDGs into national budgetary processes. IDDRI Study, No. 05/18.

19. Hege, E. and Demailly, D., 2018. NGO mobilisation around the SDGs. IDDRI Study, No. 01/18.

20. Lascoumes, P. and Le Galès, P., 2004. Gouverner par les instruments. Paris: Presses de Sciences Po.

21. Lascoumes, P. and Le Galès, P., 2007. Introduction: Understanding Public Policy through Its Instruments - From the Nature of Instruments to the Sociology of Public Policy Instrumentation. Governance, 20(1), pp. 1-21. https:// doi.org/10.1111/j.1468-0491.2007.00342.x

22. LOI n ${ }^{\circ} 2015-411$ du 13 avril 2015 visant à la prise en compte des nouveaux indicateurs de richesse dans la définition des politiques publiques. https://doi. org/10.4000/books.irdeditions. 16281

23. Martens, J., 2017. Die Agenda 2030, Nachhaltigkeitsziele und Haushaltspolitik. Schritte für Politik und Zivilgesellschaft zu einem SDG-konformen Bundeshaushalt. Bonn: Global Policy Forum.

24. Ministry of Finance and Public Credit and UNDP, 2017. Investing for Sustainable Development : How does Mexico invest in the Sustainable Development Goals? Mexico: Ministry of Finance and Public Credit and UNDP.

25. Muller, P., 2011. Les politiques publiques. Paris: Presses Universitaires de France.

26. NAC - National Audit Chamber, 2018. A Report on the preparedness of the Republic of Sudan to Implement the Sustainable Development Goals 20152030. Karthum: National Audit Chamber of Sudan.

27. Niestroy, I. [et al], 2019. Europe's approach to implementing the Sustainable Development Goals: good practices and the way forward. Bruxelles: European Parliament Policy Department for external relations.

28. OECD, 2015. Recommendations of the Council on Budgetary Governance. Paris: OECD

29. Ogien, A., 2013. Désacraliser le chiffre dans l'évaluation du secteur public. Versailles: Quae.

30. Pagnon, F., 2018. Nouveaux indicateurs de richesse et projet de loi de finances: un calendrier à respecter. IDDRI Décryptage, No. 11/18.

31. Perret, B., 2014. L'évaluation des politiques publiques. Paris: La Découverte.

32. Poghosyan, S., 2016. How to link SDGs to the Budget. IMF Public Financial Management, August 17.

33. Porter, T. M., 1995. Trust in numbers. The pursuit of objectivity in science and public life. Princeton: Princeton University Press. https://doi.org/10.1163/ 221058797x00306 
34. Ramkumar, V., 2008. Our money, our responsibility: a citizens'guide to monitoring government expenditures. Washington, D.C.: International Budget Partnership.

35. Rosanvallon, P., 2015. Le bon gouvernement. Paris: Seuil.

36. Rottenburg, R. [et al.], eds., 2015. The World of Indicators. The Making of Governmental Knowledge through Quantification. Cambridge, UK: Cambridge University Press. https://doi.org/10.1017/cbo9781316091265.001

37. Schouten, C., 2015. Open budgets for the sustainable development goals. International Budget Platform Blog, September 23.

38. UNDP, 2017a. Good Practices integrating the SDGs into development planning. Assam, India: UNDP.

39. UNDP, 2017b. Good Practices integrating the SDGs into development planning. Nepal: UNDP.

40. United Nations, 2015. Transforming our World: The 2030 Agenda for Sustainable Development. New York: United Nations. https://doi.org/10.18356/ e5a72957-en

41. Vaillé, J. and Brimont, L., 2016. Turning Sustainable Development Goals into political drivers, in France and other European countries. IDDRI Policy Brief No. 02/16.

42. World Commission on Environment and Development, 1987. Our Common Future. Oxford: Oxford University Press.

43. Young, O. R., 2017. Conceptualization: Goal setting as a strategy for earth system governance. In: N. Kanie and F. Biermann eds. Governing through goals: Sustainable Development Goals as governance innovation. Cambridge:MITPress, pp.31-51.https://doi.org/10.7551/mitpress/10894.003.0007 